\title{
Volcanic generation of tsunamis: Two New Zealand palaeo-events
}

\author{
Willem de Lange ${ }^{1}$, and Vicki Moon ${ }^{1}$ \\ School of Science, The University of Waikato, New Zealand \\ w.delange@waikato.ac.nz and v.moon@waikato.ac.nz
}

\begin{abstract}
Rapid emplacement of a mass via pyroclastic flows, or edifice failure, generates volcanic tsunamis. Physical modelling demonstrates that the efficiency of tsunami generation is influenced by the angle the mass enters the ocean. Efficiency decreases with increasing slope angle from $20^{\circ}$ to $60^{\circ}$, before increasing to a maximum at $90^{\circ}$, which corresponds to a mass falling directly into the ocean without interacting with the slope (impact tsunami). Further, in the case of surging pyroclastic flows or regressive failures, successive closely spaced events may generate larger tsunami waves than a single event of comparable volume.
\end{abstract}

It is difficult to assess if physical model results are meaningful for real world tsunami events due to limited observational data. This paper compares numerical models developed from physical simulations with palaeotsunami deposits from two New Zealand palaeo-events - pyroclastic flows from Mt Tarawera and edifice failure at Whakaari (White Island) - which constrains numerical simulations of the source mechanisms. The Mt Tarawera event involved multiple pyroclastic flows entering a lake during the AD $1314 \pm 12$ Kaharoa Eruption. The interaction of multiple closely spaced pyroclastic flows is necessary to generate the $6-7 \mathrm{~m}$ maximum wave height inferred from near source tsunami deposits. Tsunami deposits in the Bay of Plenty, dated to $2962 \pm 52$ BP, are consistent with edifice failure at Whakaari. In this case a single event with a volume of $0.23 \mathrm{~km}^{3}$ is sufficient to account for the tsunami deposits. Hence, if the failure was regressive, the successive stages were sufficiently close together to be indistinguishable from a large single event.

\section{Keywords}

Debris avalanche, physical modeling, pyroclastic flow, tsunami generation 


\section{Introduction}

Tsunami generation during volcanic eruptions has been observed within the historical record, but the mechanisms involved are not always obvious and there has been significant debate over the primary processes generating volcanic tsunami (Latter, 1981; Watts and Waythomas, 2003). Most studies indicate that rapid displacement of water by mass flows is the most effective generation mechanism, and involves either pyroclastic flows (viz. de Lange et al, 2001; Watts and Waythomas, 2003; Maeno and Imamura, 2011), or debris flows and avalanches associated with edifice failure (viz. Keating and McGuire, 2000; Tinti et al, 2001). However, there are limited observations of the processes involved resulting in uncertainty about the appropriate modelling approach (viz. Maeno and Imamura, 2007; 2011). Attribution of palaeotsunami deposits to specific volcanic sources (viz. de Lange et al, 2008; Goff et al, 2011) is difficult without numerical modelling.

\section{Modelling tsunami generation by pyroclastic flows}

Prasetya (1998) undertook a series of physical simulations of different generation mechanisms, including 2-dimensional flume experiments of subaerial flows entering water based on simulations undertaken by Monaghan et al (1997). The simulations indicated that a primary solitary wave was generated by the head of the advancing flow, with a much smaller secondary set of waves formed by turbulence behind the head. Sustained flow did not generate significant additional waves. Hence, a sliding block appeared to be a suitable approximation for the generating process.

The magnitude of the generated wave, behaviour of the flow, and the characteristics of deposits produced varied with the entry angle of the flow (Fig. 1). At low entry angles $\left(<50^{\circ}\right)$, the flow separated into a low-density component that travelled near the fluid surface, and a high-density component that travelled along the bed. The coarsest sediment was deposited first, followed by progressively finer sizes settling from suspension, producing a graded deposit that fined upwards. The wave height generated initially decreased with increasing entry angle. This matches the observations of McLeod et al (1999) who used a fixed $20^{\circ}$ entry angle.

The minimum wave height was generated for entry angles around $60^{\circ}$. At this angle, the flow retained more of the fine components resulting in a weaker surface plume. The near-bed flow scoured sediment from the base of the slope, producing a sediment free moat within the flume, with the bulk of the sediment deposited as 
a mound adjacent to the moat. The finer sediment in the surface flow predominantly was deposited on the bed on the far side of the mound (Fig.1).

With increasingly steep entry angles $>60^{\circ}$, the generated wave height increased, reaching a maximum at $90^{\circ}$ (a vertical drop analogous to an impact tsunami). The coarsest sediment within the flow was deposited directly at the base of the slope, with a secondary area of finer sediment deposition occurring further along the flume (Fig.1).

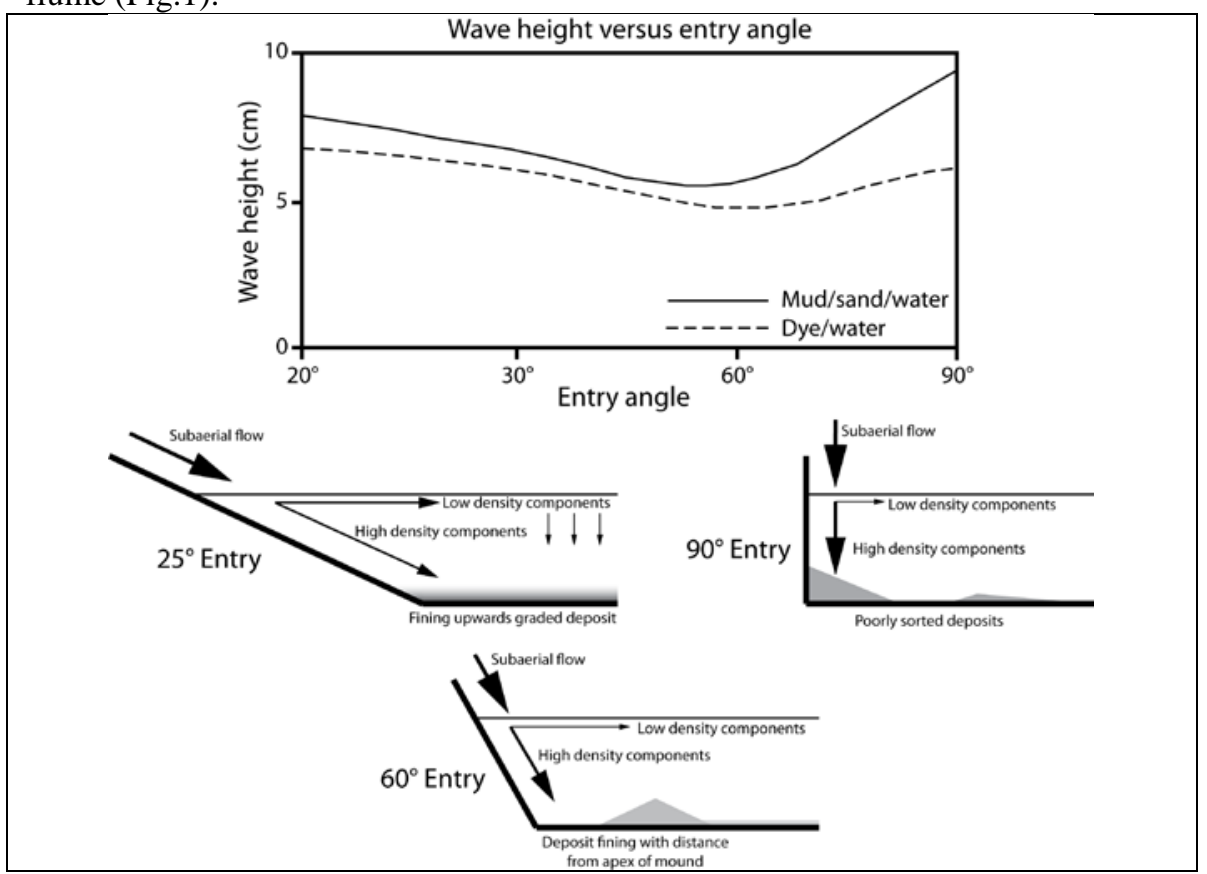

Fig 1. Summary of the results of the physical modelling of granular and dyed water flows entering a flume at different angles based on the results of Prasetya (1998).

Prasetya (1998) was unable to include hot materials in his model. However, Freundt (2003) was able to undertake physical modelling using hot granular sediment at temperatures ranging from $55^{\circ} \mathrm{C}$ to $403^{\circ} \mathrm{C}$, and two-stage ramp with an initial slope of $36^{\circ}$ and an entry angle of $26^{\circ}$. The mechanism for discharging the hot sediment produced an unsteady flow. The simulations for temperatures $<250^{\circ} \mathrm{C}$ are very similar to those of Prasetya (1998). Hotter flows tended to produce much more steam that supported the flow above the water surface, and additional wave formation was associated with hydrothermal explosions. Freundt (2003) concluded that the temperature of the flow was more important that the flow density for determining if the flow predominantly moved offshore above or below the water surface.

The observed patterns of behaviour are consistent with field observations of pyroclastic flows entering the sea and deposits attributed to this mechanism. Pyroclastic flows with relatively low entry angles tend to mix with seawater, sometimes 
with secondary hydrothermal explosions, and produce near-bed turbidity currents, and subaerial surges that flow above the water (viz. Trofimovs et al, 2006; Trofimovs et al, 2008). The patterns of behaviour are also consistent with the generation of tsunami by edifice failure (viz. Freundt et al, 2007).

Observations of pyroclastic flows at steeper angles of entry $\left(>45^{\circ}\right)$ are based on interpretation of deposits (viz. Kano, 2003), mostly associated with shallow submarine volcanoes. The deposits produced by steeper entry angles correspond to the Type 1 deposits of Kano (2003), and the main effect of increasing entry angle appears to be movement of the location of the main centre of deposition for the coarsest sediment. The centre of the deposit initially moves offshore, before moving onshore to the base of the incline.

Prasetya (1998) identified that pyroclastic flows involve multiple flows or surges, which has not been replicated in physical models; although the mechanism used by Freundt (2003) did produce some pulsing in a single flow. Prasetya (1998) undertook some numerical simulations for sequences of separate pyroclastic flows and found that it was possible to generate larger waves than for a single flow of an equivalent volume. However, he was unable to calibrate his model against observations. Freundt et al (2007) also suggested that pyroclastic flows and debris avalanches associated with edifice failure entering a shallow water body over a wide front could produce waves that exceed the normal breaking-wave limit, and hence be larger than expected. They note that this may account for landslide-induced waves of $15 \mathrm{~m}$ and $60 \mathrm{~m}$ height in the Kasu Tephra Cone Crater Lake, Papua New Guinea, and Vaiont Reservoir, Italy, respectively.

The following two examples compare numerical models developed from those of Prasetya (1998) with palaeotsunami deposits in New Zealand.

\section{Kaharoa Eruption pyroclastic tsunamis}

Lake Tarawera (Fig.2) is a volcanogenic lava-dammed marginal moat lake formed by the development of volcanic complexes within the Haroharo caldera, Okataina Volcanic Zone (Manville et al, 2007). The lake has varied significantly in extent and depth over the last $300 \mathrm{ka}$, with the present-day extent forming after the $5.6 \mathrm{ka}$ Whakatane Eruption. The deposits from the Whakatane Eruption appear to overlie a palaeosol with trees in growth position $>30 \mathrm{~m}(\sim 270 \mathrm{~m}$ asl) below present lake level at $298 \mathrm{~m}$ asl (Hodgson and Nairn, 2005), and produce a distinctive horizon in seismic reflection images of the lake sediments (Davy and Bibby, 2005).

After the Whakatane Eruption, Lake Tarawera rapidly rose to an elevation $>330 \mathrm{~m}$ asl, forming extensive terraces around the lake, before falling slowly to an elevation of $\sim 315 \mathrm{~m}$ asl at the time of the Kaharoa Eruption (Hodgson and Nairn, 2005). The $1314 \pm 12$ AD Kaharoa Eruption is a key stratigraphic marker for New Zealand as it coincides with the earliest evidence of human occupation (Hogg et $a l, 2003)$. The eruption was a complex event, with multiple episodes occurring over $\sim 4$ years from at least two vents along an 8-km long fissure (Sahetapy-Engel 
et al, 2014). The main pyroclastic flows were produced in the first $\sim 7.5$ days of an initial 2 week long explosive phase, with a series of flows entering Lake Tarawera over approximately $1.6 \mathrm{~km}$ of shoreline (Nairn et al, 2001). The flow deposits show no evidence of secondary hydrothermal explosions at the $315 \mathrm{~m}$ asl shoreline, and multibeam bathymetric data suggest the flows continue 100-200 m offshore from the present-day 298 m asl shoreline. Davy and Bibby (2005) did not identify Kaharoa pyroclastic flows in their seismic reflection surveys, but they did not approach closer than $100 \mathrm{~m}$ to the shore and did not have a shallow seismic survey in the area affected by the pyroclastic flows.

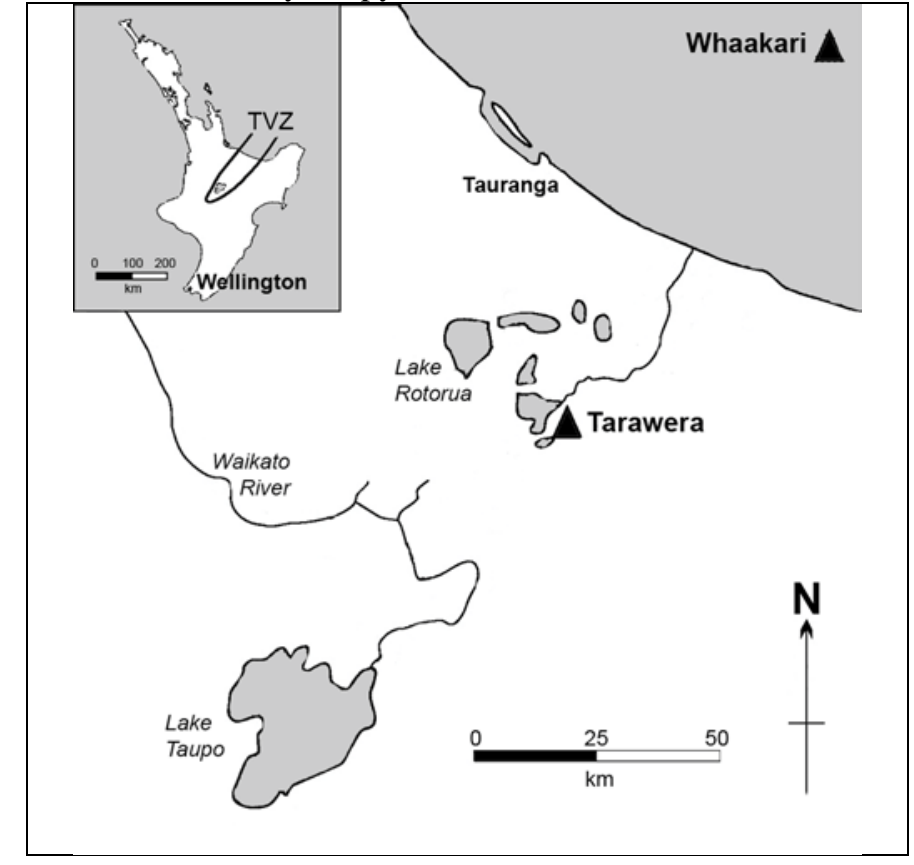

Fig 2. Locations of the two volcanic sources within the Taupo Volcanic Zone (TVZ) discussed in the text.

Hodgson and Nairn (2005) state that the lake level fell to $<303.5 \mathrm{~m}$ asl during the initial explosive phase of the eruption, before rising $\sim 30 \mathrm{~m}$ after the eruption due to damming of the lake outlet by the eruptive deposits. They suggest that this abrupt fall was due to tsunami waves overtopping the natural pre-eruption dam, and scouring out a deeper outlet channel.

Magill (2001) examined deposits near the $315 \mathrm{~m}$ asl terrace and described a palaeo-tsunami deposit consisting of a sharp erosional contact on lacustrine silts underneath two fining upwards units, overtopped by Kaharoa Tephra. The lowest unit contains cobbles that were identified as being derived from a cobble beach deposit at a lower elevation downslope. The upper unit contained gravels, which were consistent with the older beach deposits on the $315 \mathrm{~m}$ asl terrace. Based on the threshold velocities for entraining the largest clasts in each unit, Magill pro- 
posed that 2 tsunami waves of $\sim 7 \mathrm{~m}$ and $\sim 1 \mathrm{~m}$ height were responsible for the separate units.

Magill (2001) simulated the generation of tsunami waves by a range of different pyroclastic flows within the volume constraints provided by the known subaerial deposits between 315 and $298 \mathrm{~m}$ asl, and an assumed submarine terminal deposit below $298 \mathrm{~m}$ asl constrained by bathymetric contours. She calibrated the numerical model by simulating measured wind-induced seiches within Lake Tarawera. Magill (2001) then undertook a series of sensitivity tests to determine the effects of pyroclastic flow velocity, thickness, width, submerged length, and duration of the flow. Her results showed that the wave characteristics were largely determined by the initial impact at the water's edge, which depended on the flow velocity and width of shoreline affected. This is consistent with the findings of Freundt et al (2007).

Simulations based on single pyroclastic flows with characteristics inferred from the flow deposits (10-30 m.s $\mathrm{s}^{-1}$ flow velocity, $0.5-2 \mathrm{~km}$ shoreline width), produced wave heights too small to produce the observed deposits. However, the sensitivity tests suggested that multiple flow impacts on the lake would be a more effective wave generation mechanism than single pyroclastic flows. Therefore, a series of simulations were undertaken using multiple occurrences of a $20 \mathrm{~m} \cdot \mathrm{s}^{-1}$ velocity flow affecting $1 \mathrm{~km}$ of shoreline with a range of time intervals between 50 and $725 \mathrm{~s}$ at $5 \mathrm{~s}$ steps.

Considering only two pyroclastic flows, the changing time interval between flows created conditions dominated by constructive or destructive interference. There was no obvious relationship between the interference effects and the seiche periods identified for the lake, so it was assumed that this was due solely to the generating process. Overall, constructive interference occurred more often, so that most time intervals between flows modelled resulted in an increased wave height.

Using a fixed time interval of $75 \mathrm{~s}$ between flows, between 2 and 8 successive flows were simulated. There was an overall trend of increasing wave height with increasing number of flows from 2-6, and then there was no further change. The largest increase in height occurred between a single flow and 2 flows. It was found that 2 successive flows of $30 \mathrm{~m} . \mathrm{s}^{-1}$ velocity and $2 \mathrm{~km}$ shoreline width were sufficient to produce the $7 \mathrm{~m}$ tsunami required to form the lower palaeo-tsunami deposit. Additional flows would be required for slower and/or narrower flow fronts.

\section{Whakaari edifice failure tsunami}

Whakaari (White Island) is an active stratovolcano located on the continental margin, $50 \mathrm{~km}$ offshore in the Bay of Plenty, New Zealand. Moon et al (2009) identified that the present geomorphology is consistent with at least two major episodes of regressive edifice failure. Smaller failures are ongoing, with the last significant failure occurring in 1914, resulting in the deaths of all 11 inhabitants of the island (Moon et al, 2005). 
The age of prehistoric eruptions and edifice failures at Whakaari is not known. However, Shane et al (2006) collected 20 piston cores from the continental slope and rise offshore of the Bay of Plenty and identified 6 tephra units and a sequence of turbidity current deposits at the terminus of the White Island Canyon that matched the composition of Whakaari eruptives. Based on known stratigraphic markers within the cores, they dated the oldest tephra unit at $21 \mathrm{ka}$, and the turbidity current deposits as $<9.5 \mathrm{ka}$.

Palaeotsunami deposits attributed to local or regional sources have been identified at various sites around the Bay of Plenty coastline (Bell et al, 2004). One regional event, associated with up to $7 \mathrm{~km}$ of inundation, is identified at multiple sites with ages ranging from 2.2-3.0 ka. The best-constrained age is 2962 $\pm 52 \mathrm{BP}$, although Goff et al (2011) prefer an age of 2800 BP, which correlates with palaeotsunami deposits in Vanuatu. The association of sea-rafted pumice with the deposits in Vanuatu suggests a volcanic source (viz. de Lange and Moon, 2007). There is also evidence of a significant earthquake that produced up to $2 \mathrm{~m}$ of coastal subsidence in the central Bay of Plenty (Bell et al, 2004). Such an event is capable of generating the $0.17-0.45 \mathrm{~g}$ accelerations required to induce edifice failure at Whakaari (Moon et al, 2009).

Hansford (2006) simulated tsunamis generated by edifice failure of Whakaari. Unpublished side-scan and multi-beam echo sounder data from the University of Hawaii identified a possible debris avalanche deposit downslope of Whakaari, and linking to the White Island Canyon. Hansford (2006) estimated a total submarine volume of $0.23 \mathrm{~km}^{3}$ within the mapped deposit boundaries, which was in good agreement with the $0.24 \mathrm{~km}^{3}$ that Bradshaw (2004) estimated as the subaerial volume lost from Whakaari due to edifice failure.

Hansford (2006) undertook numerical simulations of tsunami generation by one or more debris avalanches resulting from edifice failure, by treating them as translational landslides and applying the methodology of Watts (1997) to produce an initial waveform. He undertook sensitivity analysis of the input parameters, since the prehistoric debris avalanche characteristics were not known, and found that entry angle and flow volume were the most important parameters. Entry angles from 5$25^{\circ}$ at $2.5^{\circ}$ increments were tested, with flow volumes of $0.14,0.28$ and $0.56 \mathrm{~km}^{3}$ (assuming that the flow volume was slightly greater than the final deposit). The width of the debris avalanche was controlled by the shape of the edifice failure as evident in the present-day geomorphology (Moon et al, 2009), and hence was kept constant at $860 \mathrm{~m}$.

The initial tsunami waveforms were then propagated onshore into the Bay of Plenty, and the resulting wave heights were compared to inferred wave heights based on the palaeo-tsunami deposits assuming that all the events dated between $2.2 \mathrm{ka}$ and 3.0 ka were a single event. The best match was obtained for entry angles of $20-25^{\circ}$ and a flow volume of $0.23 \mathrm{~km}^{3}$, suggesting that even though there is evidence for regressive failure, the successive failures behaved as a single generating event. Although, a significant component of the tsunami energy was reflected offshore by the continental slope, radial dispersion limits the potential magnitude of tsunami waves travelling northwards from New Zealand. If the palaeotsunami de- 
posits in Vanuatu and New Zealand represent a single event around $2800 \mathrm{BP}$ as suggested by Goff et al (2011), edifice failure at Whakaari is unlikely to have been the source.

\section{Conclusions}

Physical modelling and numerical simulations linked to palaeo-tsunami deposits provided useful insights into tsunami generation by mass flows. Key parameters affecting the generation process are the entry angle of the flow and flow width on entry. These determine the nature of the initial impact, and appear to be the dominant control on the characteristics of the wave leaving the generating zone, as suggested by Freundt et al (2007). Therefore, a simple moving block model for generation, as discussed by de Lange et al (2001), is adequate for simulating tsunami generation.

An additional consideration for modeling is the likelihood of multiple impacts due to a series of pyroclastic flows, or regressive edifice failure. Applying a sequence of simple block impacts provided a sensible prediction of tsunami wave height for Lake Tarawera. However, the sinusoidal forcing approach of Maeno and Imamura (2011) may be a useful alternative.

\section{References}

Bell RG, Goff J, Downes GL, Berryman KR, Walters RA, Chagué-Goff C, Barnes PM, Wright IC (2004) Tsunami hazard for the Bay of Plenty and Eastern Coromandel Peninsula: Stage 2. Environment Waikato Technical Report 2004/32, Hamilton

Bradshaw JD (2004) Aspects of slope stability for White Island Volcano, New Zealand. MSc thesis, University of Waikato. 194 pp.

Davy B, Bibby H (2005) Seismic reflection imaging of the Haraharo Caldera boundary beneath Lake Tarawera, Okataina Volcanic Centre, New Zealand. New Zeal J Geol Geop 48: 153-166

de Lange WP, Moon VG (2007). Tsunami washover deposits, Tawharanui, New Zealand. Sediment Geol 200: 232-247.

de Lange WP, Prasetya GS, Healy TR (2001) Modelling of tsunamis generated by pyroclastic flows (ignimbrites). Nat Hazards 24: 251-266

de Lange, WP, Prasetya, GS, Spiers, KC, Moon, CG (2008). Utilising palaeotsunami data for hazard assessment: Numerical modelling to identify credible sources. Solutions to Coastal Disasters 2008 - Tsunamis, Turtle Bay, Oahu, Hawaii, ASCE: 248-255.

Freundt A (2003) Entrance of hot pyroclastic flows into the sea: experimental observations. B Volcanol 65: 144-164

Freundt A, Strauch W, Kutterolf S, Schmincke H-U (2007) Volcanogenic Tsunamis in Lakes: Examples from Nicaragua and General Implications. Pure Appl Geophys 164: 527-545

Goff J, Chagué-Goff C, Dominey-Howes, D, McAdoo, B, Cronin S, Bonté-Grapetin M, Nichol S, Horrocks M, Cisternas M, Lamarche G, Pelletier B, Jaffe B, Dudley W (2011) Palaeotsunamis in the Pacific Islands. Earth-Sci Rev 107:141-148 
Hansford AJ (2006) Tsunami generation by island edifice failure, for White Island and Motuhora, New Zealand. MSc thesis, University of Waikato. $92 \mathrm{p}$.

Hodgson KA, Nairn IA (2005) The c. AD 1315 syn-eruption and AD 1904 post-eruption breakout floods from Lake Tarawera, Haroharo caldera, North Island, New Zealand. New Zeal J Geol Geop 48: 491-506

Hogg AG, Higham TFG, Lowe DJ, Palmer JG, Reimer PJ, Newnham RM (2003) Wiggle-match date for Polynesian settlement of New Zealand. Antiquity, 77: 116-125

Keating BH, McGuire WJ (2000) Island edifice failures and associated tsunami hazards. Pure Appl Geophys 157(6-8): 899-955

Kano K (2003) Subaqueous Pumice Eruptions and Their Products: A Review. In: White JDL, Smellie JL, Clague DA (eds) Explosive Subaqueous Volcanism. Geophysical Monograph 140. American Geophysical Union, pp 213-229

Latter JH (1981) Tsunamis of volcanic origin: summary of causes, with particular reference to Krakatoa, 1883. B Volcanol 44: 468-490

Maeno F, Imamura I (2007) Numerical investigation of tsunamis generated by pyroclastic flows from the Kikai caldera, Japan. Geophys Res Lett 34 L23303: 1-5

Maeno F, Imamura I (2011) Tsunami generation by a rapid entrance of pyroclastic flow into the sea during the 1883 Krakatau eruption, Indonesia. J Geophys Res 116 B09205: 1-24

Magill CR (2001) Numerical modelling of tsunami generated by mass movement. MSc thesis, University of Waikato. 198 pp.

Manville V, Hodgson KA, Nairn, IA (2007) A review of break-out floods from volcanogenic lakes in New Zealand: New Zeal J Geol Geop 50: 131-150

McLeod P, Carey S, Sparks RSJ (1999) Behaviour of particle-laden flows into the ocean: experimental simulation and geological implications. Sedimentology 46: 523-536

Moon V, Bradshaw J, de Lange W (2009) Geomorphic development of White Island Volcano based on slope stability modelling. Eng Geol 104: 16-30

Moon VG, Bradshaw JD, Smith RT, de Lange WP (2005) Geotechnical characterisation of stratocone crater wall sequences, White Island Volcano, New Zealand. Eng Geol 81:146-178

Monaghan JD, Cas RAF, Kos AM, Hallworth M (1997) Tsunami generation by pyroclastic flows, Applied Mathematics Report and Preprints, Monash University, Australia. 47 p.

Nairn IA, Self S, Cole JW, Leonard GS, Scutter C (2001) Distribution, stratigraphy, and history of proximal deposits from the c. AD 1305 Kaharoa eruptive episode at Tarawera Volcano, New Zealand. New Zeal J Geol Geop 44: 467-484

Prasetya GS (1998) Modelling volcanic tsunamis. MSc thesis, University of Waikato. 299 p.

Sahetapy-Engel S, Self S, Carey RJ, Nairn IA (2014) Deposition and generation of multiple widespread fall units from the c. AD 1314 Kaharoa rhyolitic eruption, Tarawera, New Zealand. B Volcanol 76 (836):1-28

Shane P, Sikes EL, Guilderson TP (2006) Tephra beds in deep-sea cores off northern New Zealand: implications for the history of Taupo Volcanic Zone, Mayor Island and White Island volcanoes. J Volcanol Geoth Res 154: 276-290

Tinti S, Bortolucci E, Chiavettieri C (2001) Tsunami excitation by submarine slides in shallowwater approximation. Pure Appl Geophys 158: 759-797

Trofimovs J, Amy L, Boudon G, Deplus C, Doyle E, Fournier N, Hart MB, Komorowski JC, Le Friant A, Lock EJ, Pudsey C, Ryan G, Sparks RSJ, Talling PJ (2006) Submarine pyroclastic deposits formed at the Soufrère Hills volcano, Montserrat (1995-2003): What happens when pyroclastic flows enter the ocean? Geology 34 (7): 549-552

Trofimovs J, Sparks RSJ, Talling PJ (2008) Anatomy of a submarine pyroclastic flow and associated turbidity current: July 2003 dome collapse, Soufrière Hills volcano, Montserrat, West Indies. Sedimentology 55 (3): 617-634

Watts P (1997) Water waves generated by underwater landslides. PhD thesis, California Institute of Technology, 319 pp.

Watts P, Waythomas CF (2003) Theoretical analysis of tsunami generation by pyroclastic flows. J Geophys Res 108 (B12): 2563-2563 


\section{Acknowledgments}

The authors would like to express their appreciation to the reviewers S. Williams and Prof. J. Goff, and the editors Drs. E. Lane and G. Lamarche for critiquing and improving this manuscript. 